\title{
REMOTE SENSING OF GLOBAL MONTHLY EVAPOTRANSPIRATION WITH AN ENERGY BALANCE (EB) MODEL
}

\author{
X. Chen ${ }^{1,2 *}, \mathrm{Z} \cdot \mathrm{Su}^{3}, \mathrm{Y} \cdot \mathrm{Ma}^{1,2}$ \\ ${ }^{1}$ Key Laboratory of Tibetan Environment Changes and Land Surface Processes, Institute of Tibetan Plateau Research, Chinese \\ Academy of Sciences, Beijing, China - (x.chen, ymma)@itpcas.ac.cn \\ ${ }^{2}$ CAS Center for Excellence in Tibetan Plateau Earth Sciences, Chinese Academy of Sciences, Beijing, China \\ ${ }^{3}$ Faculty of Geo-Information Science and Earth Observation, University of Twente, Enschede, The Netherlands - z.su@utwente.nl
}

KEY WORDS: canopy-air interaction、 thermal remote sensing、monthly evapotranspiration、 energy balance

\begin{abstract}
:
A global monthly evapotranspiration (ET) product without spatial-temporal gaps for 2000-2017 is delivered by using an energy balance (EB) algorithm and MODIS satellite data. It provides us with a moderate resolution estimate of ET without spatial-temporal gaps on a global scale. The model is driven by monthly remote sensing land surface temperature and ERA-Interim meteorological data. A global turbulent exchange parameterization scheme was developed for global momentum and heat roughness length calculation with remote sensing information. The global roughness length was used in the energy balance model, which uses monthly land-air temperature gradient to estimate the turbulent sensible heat, and take the latent heat flux as a residual of the available energy. This study produced an ET product for global landmass, at a monthly time step and 0.05-degree spatial resolution. The performance of ET data has been evaluated in comparison to hundreds flux sites measurements representing a broad range of land covers and climates. The ET product has a mean bias of $3.3 \mathrm{~mm} / \mathrm{month}$, RMSE value of $36.9 \mathrm{~mm} / \mathrm{month}$. The monthly ET product can be used to study the global energy and hydrological cycles at either seasonal or inter-annual temporal resolution.
\end{abstract}

\section{MANUSCRIPT}

\subsection{General Instructions}

The energy balance method, e.g. SEBS ( $\mathrm{Su} 2002)$, is structured around estimating the turbulent sensible heat flux $(\mathrm{H})$ based on a parameterization method of the aerodynamic resistance. Remote sensing energy balance model needs an estimate of roughness length to characterize the momentum and heat turbulent exchange between the surface and atmosphere. An accurate simulation of the sensible heat flux $(\mathrm{H})$ over vegetation from thermal remote sensing requires an a priori estimate of roughness length and the excess resistance parameter. Despite being the subject of considerable interest in hydrometeorology, there still does not exist a uniform method for estimating roughness length from remote sensing techniques.

The energy balance model performance is not always acceptable by scientists (Ershadi et al. 2014a; Michel et al. 2016). The model uncertainties have either been attributed to: (i) errors in the roughness parameters (Timmermans et al. 2013), (ii) land-air temperature gradient (Kwast et al. 2009), (iii) the vegetation fraction (Gibson et al. 2011), (v) the partitioning of the available energy (Webster et al. 2017). The SEBS model showed low performance over tall canopies, which was likely a consequence of the ignorance of the roughness sub-layer parameterization (Ershadi et al. 2014b). Chen et al. (2019) reported that sensible heat is significantly underestimated by SEBS at forest sites due to a high value of excess resistance $\left(k B^{-1}\right)$.
This study uses a turbulent diffusion method to simulate canopyair sensible heat. The performance of the roughness length scheme as described in (Chen et al. 2019; Chen et al. 2013) was used to calculate sensible heat flux. The energy balance (EB) model predictions of $\mathrm{H}$ for grass, crop and sparsely vegetated land compare favourably with observed values, when actual canopy height is given. $\mathrm{H}$ is significantly underestimated at forest sites due to a high value of $k B^{-1}$ in SEBS (Chen et al. 2019; Timmermans et al. 2013). Among the different physical representations for the canopy, canopy-soil mixture, and soil component, it is found that such a high $k B^{-1}$ value in SEBS is caused by the high $k B^{-1}$ value for the canopy part. The reasons for this high $k B^{-1}$ were investigated from canopy-air physical process of turbulent diffusion. The enhanced SEBS energy balance (EB) model has been verified to provide accurate simulation over different canopy structures.

\subsection{EB model}

The EB model equation is expressed as, omitting vegetation energy storage:

$$
R n=H+G_{0}+L E
$$

where $R n\left[\mathrm{~W} / \mathrm{m}^{2}\right]$ is monthly mean net radiation derived from ERA-Interim and MODIS monthly mean LST data; $G_{0}$ is the monthly mean ground heat flux $\left[\mathrm{W} / \mathrm{m}^{2}\right]$, which is taken as zero at the monthly time resolution; $H$ is monthly mean sensible heat flux $\left[\mathrm{W} / \mathrm{m}^{2}\right]$, calculated with MODIS monthly mean remote sensed LST and ERA-Interim monthly mean air temperature; and LE is the monthly mean latent heat flux $\left[\mathrm{W} / \mathrm{m}^{2}\right]$, which is computed as the residual of equation 1 .

\footnotetext{
* Corresponding author
} 
Monthly mean net radiation flux is computed as:

$$
R n=(1-\alpha) S W D+L W D-L W U
$$

where $\alpha$ is surface albedo retrieved from MODIS, GlobAlbedo product (Muller et al. 2012) is a monthly albedo, which is used here directly; SWD is the monthly mean downward surface shortwave radiation $\left[\mathrm{W} / \mathrm{m}^{2}\right]$ from ERA-Interim; LWD/LWU are the monthly mean downward/upward surface longwave radiation $\left[\mathrm{W} / \mathrm{m}^{2}\right]$. Monthly mean LWD values are obtained from ERAInterim meteorological forcing data. Monthly mean LWU $\left[\mathrm{W} / \mathrm{m}^{2}\right]$ is derived from the satellite-observed monthly mean land surface temperature (LST, in unit K) using the Stefan-Boltzmann law.

$$
L W U=\varepsilon \sigma L S T^{4},
$$

where $\sigma$ is the Stefan-Boltzmann constant $\left(5.67 \times 10^{-8} \mathrm{Wm}^{-2} \mathrm{~K}^{-4}\right)$. Land surface emissivity $(\varepsilon)$ is derived as described in Chen et al. (2013). LST is monthly mean land surface temperature derived from MODIS. The method developed by Chen et al. (2017) was used to calculate the monthly mean LST.

$$
H=k u_{*} \rho C_{p}\left(\theta_{0}-\theta_{a}\right)\left[\ln \left(\frac{z-d_{0}}{z_{0 h}}\right)-\Psi_{h}\left(\frac{z-d_{0}}{L}\right)+\Psi_{h}\left(\frac{z_{0 h}}{L}\right)\right]^{-1},
$$

where $k$ is the von Karman constant; $\rho$ is air density; $u_{*}$ is friction velocity; $C_{p}$ is specific heat for moist air; $\theta_{0}$ is the monthly potential temperature at the land surface $\left(\theta_{0}=\operatorname{LST}\left(p_{0} / p\right)^{0.286}\right.$, $p_{0}=101.3 \mathrm{kPa}$ and $p$ is the monthly ambient atmospheric pressure obtained from meteorological forcing data), derived from MODIS monthly mean LST data; $\theta_{a}$ is the monthly mean potential air temperature at reference height $\mathrm{z}(10 \mathrm{~m}$ above canopy), derived from ERA-Interim reanalysis $2 \mathrm{~m}$ air temperature; $d_{0}$ is the zero plane displacement height, derived by remote sensing method; $z_{0 h}$ is the heat roughness length (to be discussed later); $\Psi_{h}$ is the sensible heat stability correction function (Brutsaert 1999); and $L$ is the Obukhov length.

The ground heat flux $G_{0}$ is assumed to zero.

The monthly evapotranspiration amount $\left(E T_{m}\right)$ is computed by using a monthly mean evaporative fraction $\left(E F_{m}\right), E F_{m}=$ $L E /(L E+H)$, after deriving monthly mean $H$, and $L E$.

$$
E T_{m}=E F_{m} \times R n_{m}
$$

$R n_{m}$, the total monthly mean value of net radiation.

\subsection{Input Data Sets for the global ET calculation}

EB model inputs for the global ET calculation are coming from MODIS data while the others were obtained from ERA-interim reanalysis data. To avoid gaps in the time series of ET data, a specific selection of satellite-sensed datasets was done in this

\begin{tabular}{|c|c|c|c|c|}
\hline & $\begin{array}{l}\text { shortwave } \\
\text { radiation }\end{array}$ & & & \\
\hline LWD & $\begin{array}{l}\text { downward } \\
\text { surface } \\
\text { longwave } \\
\text { radiation }\end{array}$ & $\begin{array}{l}\text { ERA- } \\
\text { Interim }\end{array}$ & $\begin{array}{l}0.125 \\
\text { deg. }\end{array}$ & Reanalysis \\
\hline $\boldsymbol{R} n_{m}$ & $\begin{array}{l}\text { Monthly net } \\
\text { radiation }\end{array}$ & $\begin{array}{l}\text { ERA- } \\
\text { Interim }\end{array}$ & $\begin{array}{l}0.125 \\
\text { deg. }\end{array}$ & Reanalysis \\
\hline $\mathrm{T} 2 \mathrm{~m}$ & $\begin{array}{l}\text { air temperature } \\
\text { at } 2 \mathrm{~m} \text { height }\end{array}$ & $\begin{array}{l}\text { ERA- } \\
\text { Interim }\end{array}$ & $\begin{array}{l}0.125 \\
\text { deg. }\end{array}$ & Reanalysis \\
\hline $\mathrm{Q}$ & $\begin{array}{l}\text { specific } \\
\text { humidity }\end{array}$ & $\begin{array}{l}\text { ERA- } \\
\text { Interim }\end{array}$ & $\begin{array}{l}0.125 \\
\text { deg. }\end{array}$ & Reanalysis \\
\hline$U^{10}$ & 10-m wind speed & $\begin{array}{l}\text { ERA- } \\
\text { Interim }\end{array}$ & $\begin{array}{l}0.125 \\
\text { deg. }\end{array}$ & Reanalysis \\
\hline $\mathrm{p}$ & surface pressure & $\begin{array}{l}\text { ERA- } \\
\text { Interim }\end{array}$ & $\begin{array}{l}0.125 \\
\text { deg. }\end{array}$ & Reanalysis \\
\hline LST & $\begin{array}{l}\text { Land surface } \\
\text { temperature }\end{array}$ & $\begin{array}{l}\text { MOD11C3 } \\
\text { V5\& } \\
\text { MYD11C3 } \\
\text { V5 }\end{array}$ & 0.05 deg. & Terra/Aqua \\
\hline $\boldsymbol{h}_{\boldsymbol{c}}$ & Canopy height & $\begin{array}{l}\text { GLAS } \\
\text { (Simard et } \\
\text { al. } \\
2011 \text { )\&ND } \\
\text { VI }\end{array}$ & $0.01 \mathrm{deg}$. & Satellite \\
\hline$\alpha$ & albedo & $\begin{array}{l}\text { GlobAlbedo } \\
\text { (Muller et } \\
\text { al. 2012) }\end{array}$ & 0.05 deg. & Satellite \\
\hline NDVI & $\begin{array}{l}\text { Normalized } \\
\text { Difference } \\
\text { Vegetation Index }\end{array}$ & $\begin{array}{l}\text { MOD13C1 } \\
\text { V5\& } \\
\text { MYD13C1 } \\
\text { V5 }\end{array}$ & 0.05 deg. & Terra/Aqua \\
\hline$\overline{\mathrm{LAI}}$ & Leaf are index & $\begin{array}{l}\text { GLASS } \\
\text { (Liang et al. } \\
\text { 2013) }\end{array}$ & $0.05 \mathrm{deg}$. & Terra/Aqua \\
\hline$f c$ & $\begin{array}{l}\text { fractional } \\
\text { canopy coverage }\end{array}$ & $\begin{array}{l}\text { GLASS } \\
\text { LAI }\end{array}$ & $0.05 \mathrm{deg}$. & Terra/Aqua \\
\hline $\begin{array}{l}\text { Land } \\
\text { cover }\end{array}$ & & MCD12C1 & $0.05 \mathrm{deg}$. & Terra/Aqua \\
\hline
\end{tabular}
study. The satellite products used in this study is listed in Table 1 .

\begin{tabular}{|lllll|}
\hline $\begin{array}{l}\text { Variab } \\
\text { les }\end{array}$ & $\begin{array}{l}\text { Full variable } \\
\text { name }\end{array}$ & $\begin{array}{l}\text { Data } \\
\text { source }\end{array}$ & $\begin{array}{l}\text { Spatial } \\
\text { resolutio } \\
\text { n }\end{array}$ & $\begin{array}{l}\text { Method/Sat } \\
\text { ellite sensor }\end{array}$ \\
\hline SWD & $\begin{array}{l}\text { downward } \\
\text { surface }\end{array}$ & $\begin{array}{l}\text { ERA- } \\
\text { Interim }\end{array}$ & $\begin{array}{l}0.125 \\
\text { deg. }\end{array}$ & Reanalysis \\
\hline
\end{tabular}

Table 1 input data sets used for the et estimates.

\section{GLOBAL ET EVALUATION}

\subsection{ET evaluation}

ET stations are distributed among Australian, China, Europe, and the US. The collection of flux towers in this study covers a broad range of biomes and climate types such as the semi-arid tropics, subtropics, Mediterranean savannas, temperate grasslands, temperate forests, boreal forests and arctic wetlands. A total of 238 reliable sites were selected from all the flux sites of FLUXNET2015 Dataset, Ozflux (http://www.ozflux.org.au/), European Fluxes Database Cluster (http://www.europefluxdata.eu/), and ChinaFlux network, which covers a wide range of ecosystems.

Global monthly ET was estimated using the enhanced parameterization method (Chen et al. 2013) combined in the ET model. The model was driven by monthly remote sensing land surface temperature observations and monthly meteorological data (Table 1). An evaluation of the derived remote sensing monthly ET at 238 flux sites showed the MB (mean bias)/RMSE (root mean square error) for ET is $11.79 / 48.95,6.26 / 33.79$, $1.79 / 31.65$ and $-5.27 / 33.33 \mathrm{~mm} / \mathrm{month}$ for flux towers in Australian, American, China and EU respectively. (Figure 1). The average MB and RMSE is about 3.6 and $36.9 \mathrm{~mm} / \mathrm{month}$

In practice, ET is derived from the bulk transfer formulation using measurements of other quantities. Any uncertainties associated with the satellite input will cause uncertainties in the evaluation of ET. Here, we have assumed that the foliage 
temperature is constant throughout the canopy layers, which make it easier to use MODIS LST to calculate the turbulent heat flux and ET. Meanwhile, it will introduce some uncertainties in the ET data.
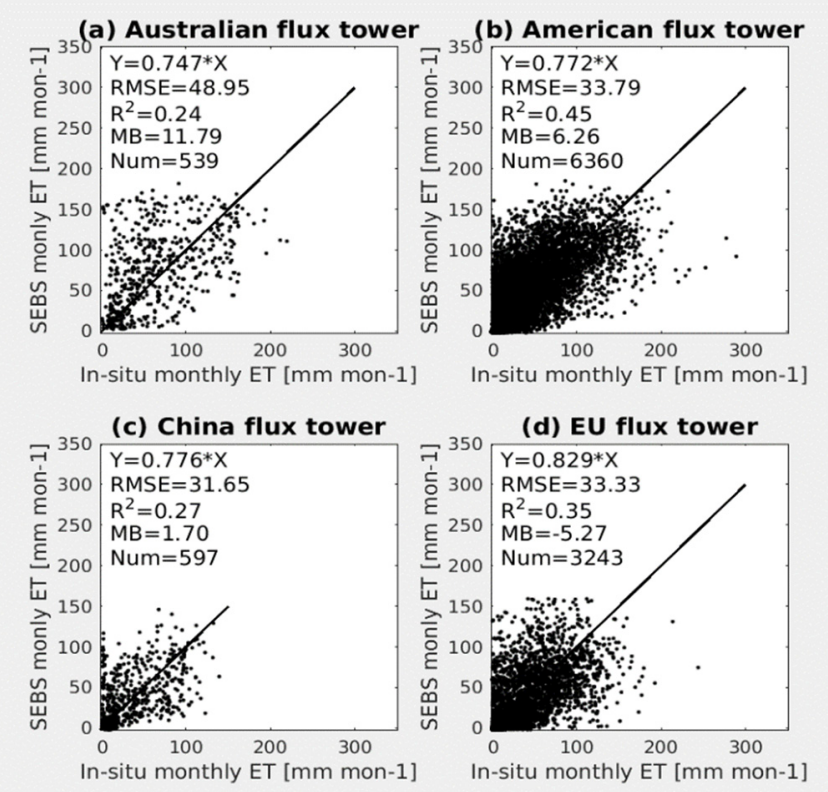

Fig. 1 Scatter density of the EB model estimates against monthly ET observation at 238 flux sites.

\subsection{Comparison with GLEAM ET}

The EB global ET (Figure 2) generally shows highest values in the tropics, lowest values in arid area, intermediate values in midlatitude regions. The general spatial patterns for our results (middle panel) are similar to that of GLEAM (Miralles et al. 2011). However, our averaged annual ET estimates over the tropical forests of the Amazon and South Africa are lower than those from GLEAM. Our Sahel desert, Middle East, and arid deserts have ET estimates close to those of GLEAM. The EB ET estimates for the African Kongo and Niger River basin are higher than those of GLEAM.

\subsection{Seasonal variation of the remote sensing ET at flux sites}

The remote sensing ET product represents the seasonal variations very well at most of the flux tower points. Figure 3 shows time series of monthly ET simulation and in-situ observation at 12 China flux sites. The flux sites were often used to validate global ET dataset. Hereby, we also used them for the same purpose. The remote sensing ET dataset generally grasp the seasonal variation of ET.

Some of the ET error source at the flux sites is due to that ERAinterim net radiation. Part of the time lag in figure 3 can be explained by the errors in the different model input dataset.

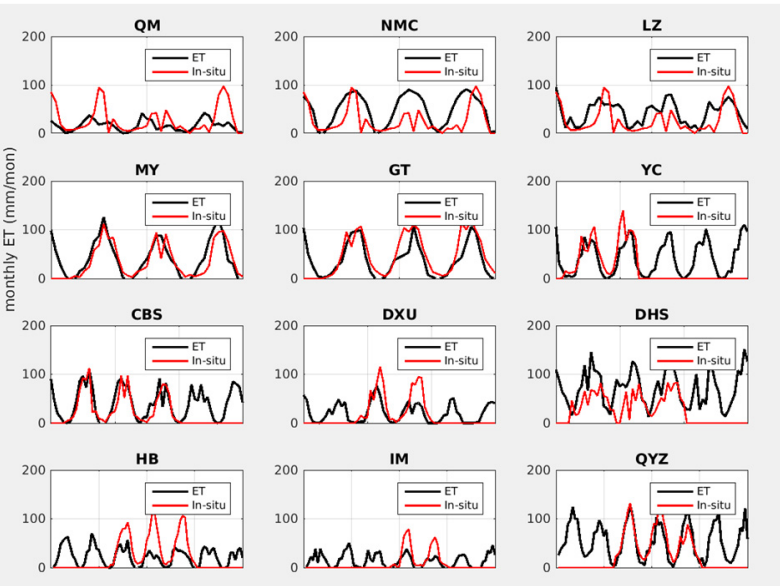

Fig. 3 Time series of monthly ET simulation and in-situ observation at 12 China flux sites. QM-Qomolangma site, NMCNamco, LZ- Linzhi, MY- Miyun, GT-Guantao, YC-Yucheng, CBS-Changbaishan, DXU-Dangxiong, DHS-Dinghushan, HBHaibei, IM-Neimeng, QYZ-Qianyanzhou site.

Figure 4 shows the spatial distribution of Chirps Precipitation minus ET from this study. It is clear that the ET over the North China, Nile delta, Indus river region, Texas, New Mexico, Kansas and western American are higher than their precipitation. These regions are agricultural land. Therefore, ET in these regions have a high dependence on irrigation. Meanwhile, the irrigation influence on the land surface ET has never been reported by other remote sensing ET dataset. Our result shows that the energy balance has a high promise to produce a global ET product which take into account irrigation impacts on the global water cycle.

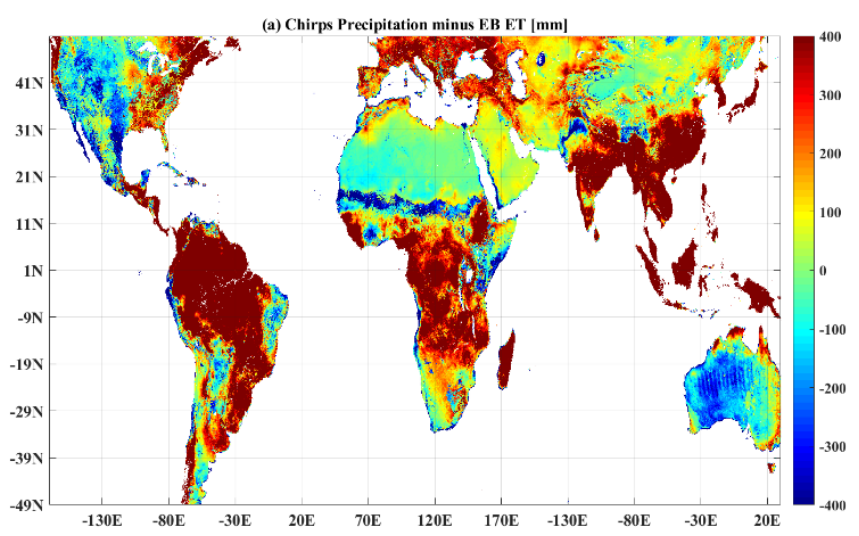

Figure 4 Annual Precipitation minus annual ET (mm) from EB

Most of the currently available ET products have been listed in the Table 2. Most of the products rely on one of several main calculation methods, such as Penman-Monteith, PriestleyTaylor and Surface energy balance. ESA WACMOS-ET project reports indicate that there is no single best-performing algorithm across all biome and forcing types among these algorithms (Michel et al. 2016). The ET products have used different satellite data. GLEAM is mostly based on microwave satellite data. CSIRO, MOD16, PB-JPL and ET-monitor, LSA-SAF use visible sensor data from several satellites. 


\begin{tabular}{|l|c|c|c|c|c|}
\hline $\begin{array}{l}\text { ET } \\
\text { algorithms }\end{array}$ & $\begin{array}{l}\text { Thermal } \\
\text { sensors }\end{array}$ & $\begin{array}{l}\text { Visible } \\
\text { sensors }\end{array}$ & $\begin{array}{l}\text { Microwave } \\
\text { band }\end{array}$ & $\begin{array}{l}\text { Energy } \\
\text { balance }\end{array}$ & $\begin{array}{c}\text { Open- } \\
\text { source }\end{array}$ \\
\hline GLEAM & $\mathrm{X}$ & $\sqrt{ }$ & $\sqrt{ }$ & $\mathrm{X}$ & $\mathrm{X}$ \\
\hline CSIRO & $\mathrm{X}$ & $\sqrt{ }$ & $\mathrm{X}$ & $\mathrm{X}$ & $\mathrm{X}$ \\
\hline MOD16 & $\mathrm{X}$ & $\sqrt{ }$ & $\mathrm{X}$ & $\mathrm{X}$ & $\mathrm{X}$ \\
\hline PT-JPL & $\mathrm{X}$ & $\sqrt{ }$ & $\mathrm{X}$ & $\mathrm{X}$ & $\mathrm{X}$ \\
\hline $\begin{array}{l}\text { ET- } \\
\text { monitor }\end{array}$ & $\mathrm{X}$ & $\sqrt{ }$ & $\mathrm{X}$ & $\mathrm{X}$ & $\mathrm{X}$ \\
\hline LSA-SAF & $\mathrm{X}$ & $\sqrt{ }$ & $\mathrm{X}$ & $\sqrt{ }$ & $\mathrm{X}$ \\
\hline EB & $\sqrt{ }$ & $\sqrt{ }$ & $\sqrt{ }$ & $\sqrt{ }$ & $\sqrt{ }$ \\
\hline
\end{tabular}

spatial pattern is generally similar. Meanwhile, there are some regions having a high difference.

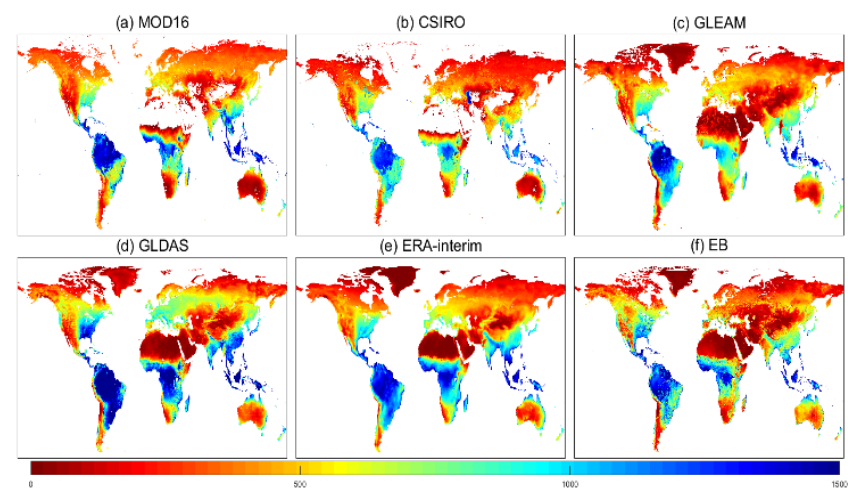

Table 2: ET algorithms comparison

Recently, scientists have produced a multi-product ensemble, with weighting based on validation analyses and uncertainty assessments. It is proposed in literature as the best way forward in the long-term goal to develop a robust benchmark data set of continental evaporation (Miralles et al. 2016). However, the ensemble products always have problem of low spatial resolution and short time coverage.

\begin{tabular}{|c|c|c|c|c|}
\hline ET & Res. & Method & Satellite data & Ref. \\
\hline $\begin{array}{l}\text { GLEA } \\
\mathbf{M} \\
\text { (V3.2b) }\end{array}$ & $\begin{array}{l}2003-2017, \\
0.25 \mathrm{deg}\end{array}$ & $\begin{array}{l}\text { Priestley- } \\
\text { Taylor }\end{array}$ & $\begin{array}{l}\text { SMMR / } \\
\text { SSMI /AMSR- } \\
\text { E/MODIS/AI } \\
\text { RS / MODIS } \\
\text { NDVI, albedo }\end{array}$ & $\begin{array}{l}\text { Marten } \\
\text { s et al. } \\
\text { (2017) }\end{array}$ \\
\hline CSIRO & $\begin{array}{l}\text { 1983-2006, } \\
\text { monthly, } \\
8 \mathrm{~km}\end{array}$ & $\begin{array}{l}\text { Penman- } \\
\text { Monteith }\end{array}$ & AVHRR & $\begin{array}{l}\text { Zhang } \\
\text { et al. } \\
(2010)\end{array}$ \\
\hline MOD16 & $\begin{array}{l}2000-2014, \\
\text { every } 8 \\
\text { days, } 1 \mathrm{~km}\end{array}$ & $\begin{array}{l}\text { Penman- } \\
\text { Monteith }\end{array}$ & MODIS & $\begin{array}{l}\text { Mu et } \\
\text { al. } \\
(2011)\end{array}$ \\
\hline PT-JPL & $\begin{array}{l}\text { 1984- } \\
\text { 2006, daily } \\
\text {, , } 1 \text { deg. }\end{array}$ & $\begin{array}{l}\text { Priestley- } \\
\text { Taylor }\end{array}$ & AVHRR & $\begin{array}{l}\text { Fisher } \\
\text { et al. } \\
(2008)\end{array}$ \\
\hline $\begin{array}{l}\text { ET- } \\
\text { monitor }\end{array}$ & $\begin{array}{l}\text { 2008-2012, } \\
\text { daily, } 1 \mathrm{~km}\end{array}$ & $\begin{array}{l}\text { Shuttleworth- } \\
\text { Wallace }\end{array}$ & $\begin{array}{l}\text { MODIS } \\
\text { NDVI, } \\
\text { albedo, } \\
\text { Microwave } \\
\text { soil } \\
\text { moisture, } \\
\text { GLASS, } \\
\text { CMORPH, } \\
\text { ERA-Interim }\end{array}$ & $\begin{array}{l}\text { Zheng } \\
\text { et al. } \\
\text { (2016) }\end{array}$ \\
\hline $\begin{array}{l}\text { LSA- } \\
\text { SAF }\end{array}$ & $\begin{array}{l}2009-2017 \\
\text { daily, } 5 \mathrm{~km}\end{array}$ & SVAT & $\begin{array}{l}\text { EUMETSAT } \\
\text { Satellites }\end{array}$ & $\begin{array}{l}\text { Ghilain } \\
\text { et al. } \\
\text { (2011) }\end{array}$ \\
\hline EB & $\begin{array}{l}\text { 2001-2017, } \\
\text { monthly, } \\
0.05 \text { deg. }\end{array}$ & $\begin{array}{l}\text { Surface energy } \\
\text { balance \& } \\
\text { turbulent } \\
\text { parameterizati } \\
\text { on method }\end{array}$ & $\begin{array}{l}\text { MODIS, ERA- } \\
\text { Interim }\end{array}$ & $\begin{array}{l}\text { This } \\
\text { study }\end{array}$ \\
\hline
\end{tabular}

Table 3: Available global/continental ET products based on satellite data

Figure 5 shows the global maps of ET from MOD16, CSIRO, GLEAM, GLDAS, ERA-Interim and ET of this study. Their
Figure 5 Annual ET from MOD16 (a), CSIRO (b), GLEAM (c), GLDAS (d), ERA-Interim (e) and EB (f)

\section{DISCUSSION}

This paper presents an energy balance ET retrieval methodology; optical remote sensing data were used to describe the dynamic variation of land surface. ERA-Interim Reanalysis data was used to represent the variation in air temperature, wind speed, solar radiation. The fluxes of sensible heat and latent heat calculated with the enhanced SEBS energy balance (EB) model were closely correlated to the measured values. The spatial-temporal resolution of the ET product is adequate for many water resources and agricultural applications. It is also sufficient for studying global water balance.

The thermal status of land surface is described by using MODIS LST. Amazon tropical forest region has a relative bigger bias due to the gaps of LST in MODIS monthly product. More thermal remote sensed LST dataset are needed to improve the ET accuracy for the high cloud frequency regions.

\section{ACKNOWLEDGEMENTS}

This study was supported by CAS Pioneer Hundred Talents Program. We would like to thank the European Center for Medium-Range Weather Forecasts (ECMWF) for providing the ERA-interim reanalysis datasets, NASA's Land Processes Distributed Active Archive Center (LP DAAC) for the MODIS series products. All the MODIS data are downloaded from http server: e4ft101.cr.usgs.gov. AmeriFlux, OzFlux, European Fluxes Database Cluster, ChinaFlux and TPE are acknowledged for the flux data. Jiule $\mathrm{Li}$ is funded by the National Key Basic Research Program (2018YFB1307504). The ET data is freely open on the web: http://en.tpedatabase.cn/portal/MetaDataInfo.jsp?MetaDataId=2 49454 or by contact email: x.chen@itpcas.ac.cn

\section{REFERENCES}


Brutsaert, W. (1999). Aspects of bulk atmospheric boundary layer similarity under free-convective conditions. Rev. Geophys., $37,439-451$

Chen, X., Massman, W.J., \& Su, B.Z. (2019). A column canopyair turbulent diffusion method for different canopy structures. Journal of Geophysical Research: Atmospheres, 124, 488-506

Chen, X., Su, B.Z., Ma, Y., Cleverly, J., \& Liddell, M. (2017). An Accurate Estimate of Monthly Mean Land Surface Temperatures from MODIS Clear-Sky Retrievals. Journal of Hydrometeorology, 18, 2827-2847

Chen, X., Su, Z., Ma, Y., Yang, K., Wen, J., \& Zhang, Y. (2013). An improvement of roughness height parameterization of the Surface Energy Balance System (SEBS) over the Tibetan Plateau. Journal of Applied Meteorology and Climatology, 52, 607-622

Ershadi, A., McCabe, M.F., Evans, J.P., Chaney, N.W., \& Wood, E.F. (2014a). Multi-site evaluation of terrestrial evaporation models using FLUXNET data. Agricultural and Forest Meteorology, 187, 46-61

Ershadi, A., McCabe, M.F., Evans, J.P., Chaney, N.W., \& Wood, E.F. (2014b). Multi-site evaluation of terrestrial evaporation models using FLUXNET data. Agricultural and Forest Meteorology, 187, 46-61

Fisher, J.B., Tu, K.P., \& Baldocchi, D.D. (2008). Global estimates of the land-atmosphere water flux based on monthly AVHRR and ISLSCP-II data, validated at 16 FLUXNET sites. Remote Sensing of Environment, 112, 901-919

Ghilain, N., Arboleda, A., \& Gellens-Meulenberghs, F. (2011). Evapotranspiration modelling at large scale using near-real time MSG SEVIRI derived data. Hydrol. Earth Syst. Sci., 15, 771-786 Gibson, L.A., Münch, Z., \& Engelbrecht, J. (2011). Particular uncertainties encountered in using a pre-packaged SEBS model to derive evapotranspiration in a heterogeneous study area in South Africa. Hydrol. Earth Syst. Sci., 15, 295-310

Kwast, v.d.J., Timmermans, W., Gieske, A., Su, Z., Olioso, A., Jia, L., Elbers, J., Karssenberg, D., \& de Jong, S. (2009). Evaluation of the Surface Energy Balance System (SEBS) applied to ASTER imagery with flux-measurements at the SPARC 2004 site (Barrax, Spain). Hydrol. Earth Syst. Sci., 13, 1337-1347

Liang, S., Zhao, X., Liu, S., Yuan, W., Cheng, X., Xiao, Z., Zhang, X., Liu, Q., Cheng, J., Tang, H., Qu, Y., Bo, Y., Qu, Y., Ren, H., Yu, K., \& Townshend, J. (2013). A long-term Global LAnd Surface Satellite (GLASS) data-set for environmental studies. International Journal of Digital Earth, 6, 5-33

Martens, B., Miralles, D.G., Lievens, H., van der Schalie, R., de Jeu, R.A.M., Fernández-Prieto, D., Beck, H.E., Dorigo, W.A., \& Verhoest, N.E.C. (2017). GLEAM v3: satellite-based land evaporation and root-zone soil moisture. Geosci. Model Dev., 10, 1903-1925

Michel, D., Jiménez, C., Miralles, D.G., Jung, M., Hirschi, M., Ershadi, A., Martens, B., McCabe, M.F., Fisher, J.B., Mu, Q., Seneviratne, S.I., Wood, E.F., \& Fernández-Prieto, D. (2016). The WACMOS-ET project - Part 1: Tower-scale evaluation of four remote-sensing-based evapotranspiration algorithms. Hydrol. Earth Syst. Sci., 20, 803-822
Miralles, D.G., De Jeu, R.A.M., Gash, J.H., Holmes, T.R.H., \& Dolman, A.J. (2011). Magnitude and variability of land evaporation and its components at the global scale. Hydrol. Earth Syst. Sci., 15, 967-981

Miralles, D.G., Jiménez, C., Jung, M., Michel, D., Ershadi, A., McCabe, M.F., Hirschi, M., Martens, B., Dolman, A.J., Fisher, J.B., Mu, Q., Seneviratne, S.I., Wood, E.F., \& Fernández-Prieto, D. (2016). The WACMOS-ET project - Part 2: Evaluation of global terrestrial evaporation data sets. Hydrol. Earth Syst. Sci., $20,823-842$

Mu, Q., Zhao, M., \& Running, S.W. (2011). Improvements to a MODIS global terrestrial evapotranspiration algorithm. Remote Sensing of Environment, 115, 1781-1800

Muller, J.-P., López, G., Watson, G., Shane, N., Kennedy, T., Yuen, P., Lewis, P., Fischer, J., Guanter, L., Domench, C., Preusker, R., North, P., Heckel, A., Danne, O., \& Krämer, U. (2012). The ESA GlobAlbedo Project for mapping the Earth's land surface albedo for 15 Years from European Sensors. In, IEEE Geoscience and Remote Sensing Symposium (IGARSS) Munich, Germany

Simard, M., Pinto, N., Fisher, J.B., \& Baccini, A. (2011). Mapping forest canopy height globally with spaceborne lidar. $J$. Geophys. Res., 116, G04021

$\mathrm{Su}$, Z. (2002). The Surface Energy Balance System(SEBS) for estimation of turbulent heat fluxes. Hydrology and Earth System Sciences, 6, 85-99

Timmermans, J., Su, Z., van der Tol, C., Verhoef, A., \& Verhoef, W. (2013). Quantifying the uncertainty in estimates of surfaceatmosphere fluxes through joint evaluation of the SEBS and SCOPE models. Hydrol. Earth Syst. Sci., 17, 1561-1573

Webster, E., Ramp, D., \& Kingsford, R.T. (2017). Incorporating an iterative energy restraint for the Surface Energy Balance System (SEBS). Remote Sensing of Environment, 198, 267-285

Zhang, K., Kimball, J.S., Nemani, R.R., \& Running, S.W. (2010). A continuous satellite-derived global record of land surface evapotranspiration from 1983 to 2006. Water Resources Research, 46, W09522

Zheng, C., Jia, L., Hu, G., Lu, J., Wang, K., \& Li, Z. (2016). Global evapotranspiration derived by ETMonitor model based on earth observations. In, Geoscience and Remote Sensing Symposium (IGARSS), 2016 IEEE International (pp. 222-225): IEEE 